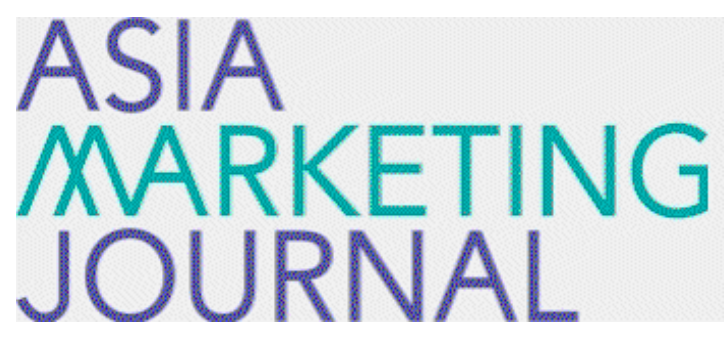

ASIA MARKETING JOURNAL

Volume 14 | Issue 3

Article 7

10-30-2012

\title{
The Interaction Effects of the Shopping Situation and the Product Display Type on the Consumer Response in Mobile Shopping
}

Seung Hoon Choi

Dong II Lee

Hye Jun Lee

Follow this and additional works at: https://amj.kma.re.kr/journal

Part of the Marketing Commons

\section{Recommended Citation}

Choi, Seung Hoon; Lee, Dong Il; and Lee, Hye Jun (2012) "The Interaction Effects of the Shopping Situation and the Product Display Type on the Consumer Response in Mobile Shopping," Asia Marketing Journal: Vol. 14 : Iss. 3 , Article 7.

Available at: https://doi.org/10.53728/2765-6500.1492

This Article is brought to you for free and open access by Asia Marketing Journal. It has been accepted for inclusion in Asia Marketing Journal by an authorized editor of Asia Marketing Journal. 


\title{
The Interaction Effects of the Shopping Situation and the Product Display Type on the Consumer Response in Mobile Shopping*
}

\author{
Seung-Hoon Choi** \\ Dong Il Lee*** \\ Hyejun Lee Le***$^{* *}$
}

The purpose of this research is to investigate the effects of the product display type on the consumers purchase intention, attitude toward store, and revisit intention in the various mobile shopping situations. To test the hypothesis, between-subjects experiment with 3 mobile shopping situations (outdoor place. public transportation, commercial facilities) by 3 product display types (search, category, product) was conducted, and analyzed with ANCOVA (analysis of covariance).

The result of the experiment shows there are no main effects of the mobile shopping situations and the product display types, but the interaction effects of the product display type and the mobile shopping situation on the purchase intention and the revisit intention are statistically significant. However the attitude toward the store is not affected by the treatments.

Experiment results suggest that the positive consumer responses in terms of the purchase and revisit intention can be achieved when the product display is matched with the situation in the mobile shopping setting. Controlling consumers' evaluation on the product information and their experience of online shopping, we can take these effect as the results of match-up between the product display type and the situational factors surrounding mobile shopping.

The result provides strong support for the location-based service in mobile shopping. Most of the mobile device can utilize the consumers' location which can be easily interpreted as the situational factors. With regard of the level of the external stimulation, the shopping service providers can offer the main interface with the right match with the consumers situations. When the external stimulation level is high, they should provide the category display or product display in the target promotion in their mobile shopping apps. However if the target is on the way with the low external stimulation level, they should provide the search format as the main interface in their apps. More interestingly, this kind of manipulation does not affect the consumers attitude toward the store according to our research result. Future research direction is discussed.

Key words: Mobile shopping. Shopping situation, Product display, Consumer response

\footnotetext{
* This work was supported by the research fund for future strategy of Sejong University in 2010.

** Researcher, Institute of Distribution and Franchise, Sejong University(csh8331@naver.com). First author

*** Associate professor. College of Business, Sejong University(donlee@sejong.ac.kr). Corresponding author

**** Senior Researcher. Institute of Distribution and Franchise, Sejong University(leehyejun@daum.net). Third author
} 


\section{Introduction}

The total sales of the online shopping market in South Korea is more than $\$ 25$ billion, whereas the overall sales of the mobile shopping market (so called m-commerce) is only approximately \$9 million(KOLSA, 2010). Online consumers' shopping experience in the mobile environment is reported as limited in the smart phone era. KCC (Korea Communications Commission) reported that the number of users to the smart phone exceeded 9,260,000 at the end of 2011. which is 18.1 percent of all mobile phone users. However, only 13.9 percent of smart phone users experienced mobile shopping. And the most of transactions were micropayment under $\$ 45$ in the report of KCCI (Korea Chamber of Commerce $\&$ Industry).

Many researchers pointed out the relatively slow growth of the mobile shopping as the main reason for the limits of the mobile user interfaces. And many practitioners have tried to find the solutions by enhancing the user interface similar to that of PC based shopping environment (Jauréguiberry, 2000: Laszlo, 2009: Lee and Benbasat, 2004: Swilley and Hofacker, 2006).

But KISA (Korea Internet and Security Agency, 2011) pointed out the main reason for using mobile Internet is people's need for the immediate access to the Internet regardless of place and time. Actually, most of people connect to the mobile Internet when they are out of the home or office, whereas PC Internet is used when they are at home.

The unique needs for the mobile access depends on the usage environment. So we should enhance the mobile user interface based on the usage environment. People could focus on the information of the website without interruption when they get on the PC Internet at home, whereas they might face many kinds of difficulties which interrupt their attention on the task in the outside such as the attention of the others, noise, and obstructions. Furthermore, interruption level may be different according to the place where they are, such as outdoor, commercial facilities, or a public transportation. Therefore, unlike PC-based Internet, mobile interfaces have to match up with the environment with different level of outside interruptions.

Although the factors reflecting the different levels of outside interruptions could play a great roles in the mobile shopping, these factors have not adequately considered by the most of Korean mobile shopping companies yet. The majority of the mobile shopping applications present same interface wherever consumers access.

In this point of view, it is necessary to find the effective way of mobile display types matching with the usage environment. However, there are only a few research focusing on the differences between preference formation process of mobile environment and the PC-based one (Quester. 1998). Some studies stated that we should consider the various situational factors such as 
time and place form the distinct characteristics of mobile shopping from PC based online shopping (Jauréguiberry, 2000: Laszlo, 2009: Lee and Benbasat, 2004: Swilley and Hofacker. 2006). But only a few studies have been empirically test the effects of mobile shopping situation on the consumers preference formation in terms of the shopping situations (Jauréguiberry, 2000: Laszlo, 2009: Lee and Benbasat, 2004: Swilley and Hofacker, 2006). Therefore, the goal of this research is to investigates the interaction effects of the product display types and the mobile shopping situations on the following consumers responses.

\section{Theoretical Backgrounds and Research Model}

\subsection{Uniqueness of Mobile Usage Situation}

According to the KISA Report 2011, the place where people most frequently access the mobile Internet is their home (70.5 percent). Following places after home on the list are public transportation such as bus or subway ( 65.2 percent), outdoors (63.2 percent), and commercial facilities ( 40.5 percent). People could also access to the PC-based Internet. The place with highest access rate is home ( 81.9 percent), the next are work place (28.3 percent), public transportation (14.2 percent), commercial facilities (10.7 percent), and outdoors (8.1 percent). Though home is the common place of most frequent accessing the Internet in mobile or PC, PC-based Internet access rate is much higher than mobile Internet. As the place of mobile Internet access shows, most of the mobile Internet users took the advantage of the immediate access to the Internet regardless of time and place ( 88.8 percent). These indicators readdress the unique characteristics of the mobile usage situations which have been argued by the previous academic researches shown in Table 1. The uniquenesses of mobile usage situation are locationspecificity, time-sensitivity, and personalized relationships (Swilley and Hofacker, 2006). increasing the density of time and creating a double time (Jauréguiberry, 2000), time, place, and context (Lee and Benbasat, 2004), to save time, to fill time (Laszlo, 2009), and current situation and usage of time (Albers, 2007). All of these studies commonly emphasize that the uniqueness of mobile usage situation is free from restrictions of place and time.

The perspective of different usage environment suggests that the early definitions for the mobile commerce did not capture the unique characteristics in the appropriate manner. As shown in Table 2, most of the early definitions for the mobile commerce are dealt only within the context of technologies, so they treat the mobile commerce as the extended electronic commerce in the PC-based connections. However, some researches already pointed out the needs 
〈Table 1〉 Distinctive Characteristics of Mobile Usage Situation

\begin{tabular}{c|c}
\hline Researcher & Uniqueness of Mobile Usage Situation \\
\hline \hline Swilley and Hofacker (2006) & Location-specificity, Time-sensitivity, Personalized relationships \\
\hline Jauréguiberry (2000) & Increasing the density of time, Creating a double time \\
\hline Lee and Benbasat (2004) & Time. Place and Context \\
\hline Laszlo (2009) & To save time, To fill time \\
\hline Albers (2007) & Current Situation. Usage of Time \\
\hline
\end{tabular}

for the new perspectives (Swilley and Hofacker. 2006). Lee and Benbasat(2004) also argues that the fundamental differences between online and mobile shopping should be explained by the variety of usage situation in terms of time. place, and context.

This study proposes that mobile shopping consumers may be influenced by situational factors such as usage time or place more than the $\mathrm{PC}$ based online shopping consumers while they make motivations toward the mobile shopping. This could be interpreted that consumer may want the type of product information presented by mobile device to be different according to their situation.

So our definition for the mobile shopping is the shopping behavior depending more on the situational factors within the context enabled by the mobile devices. So we proceed with influences of the situational factors on consumers.

\subsection{Influence of Situational Factors on Consumer Response}

Belk (1974) defined the consumer situations as all the observable factors surrounding consumer particularly in the context of time and place regardless of the individual's knowledge and the attributes of the choice alternatives. So understanding the situational influences on consumer's decision making, we can adapt the revised $\mathrm{S}-\mathrm{O}-\mathrm{R}$ paradigm suggesting not only ob-

〈Table 2〉 Early Definitions of the Mobile Commerce

\begin{tabular}{c|c}
\hline Researcher & Definition \\
\hline \hline Frolick and Chen (2004) & Wireless e-commerce \\
\hline Dholakia (2004) & E-cornmerce via mobile or wireless devices \\
\hline Siau et al. (2001) & $\begin{array}{c}\text { The new types of e-commerce transactions conducted through } \\
\text { mobile devices using wireless telecommunication networks and } \\
\text { other wired e-commerce technologies }\end{array}$ \\
\hline Mennecke and Strader (2001) & $\begin{array}{c}\text { E-commerce activities carried out via a mobile terminal such } \\
\text { as a cell phone or PDA }\end{array}$ \\
\hline Walsh. Davison and Brown (2000) & Extended e-commerce via cell phone \\
\hline
\end{tabular}


jects but also situations independently affect consumers' cognitive process, and then lead to response (Belk, 1975). According to S-O-R paradigm, as the gap between consumer's actual state and ideal state widens over threshold, situational factors are activated(see Figure 1).

Interestingly, the effect of situational factors on the consumer behavior has been widely explored in the field of behavioral economics, For instance, Thaler (1985) shows that given the same brand of bear, consumer's willingness to pay is much higher when it is supposed to be sold in a fancy resort than in an ordinary super market. It is because higher reference price was made by the situational factor like fancy resort. And $\mathrm{Na}$ (2006) also argues that the user situations affect the product evaluation. Considering the context effect, mobile shopping consumer may make the different reactions compared with the online consumers when they make purchase decisions because of the different context. What matters is how mobile shopping situations could be classified regarding the subsequent responses. Albers (2007) suggested that mobile shopping consumer should be classified based upon their situations and needs, and offers with the information such as product information or advertisement for the sake of positive consumer response. But the classification of the mobile shopping situation has been rarely made theoretically up to now.

However, Menon and Kahn (1995) suggested that consumers' shopping situation could be classified by the level of external stimulation to a certain object. Their study indicates that consumers with higher external stimulation level have tendency to decrease variety seeking behavior for reducing the complexities in the situation. This means that if there are many alternatives, people try to reduce the cognitive efforts by choosing the same brand of items just out of habit. This applies to mobile shopping situation, when people are outside, there are many external stimulation factors such as other people's attention, noise, and obstructions, so they don't afford variety seeking behavior to search various product information.

As mentioned earlier, we can classify the place and time for the mobile Internet according to the external stimulation levels because the place

〈Figure 1〉 Revised S-0-R Paradigm

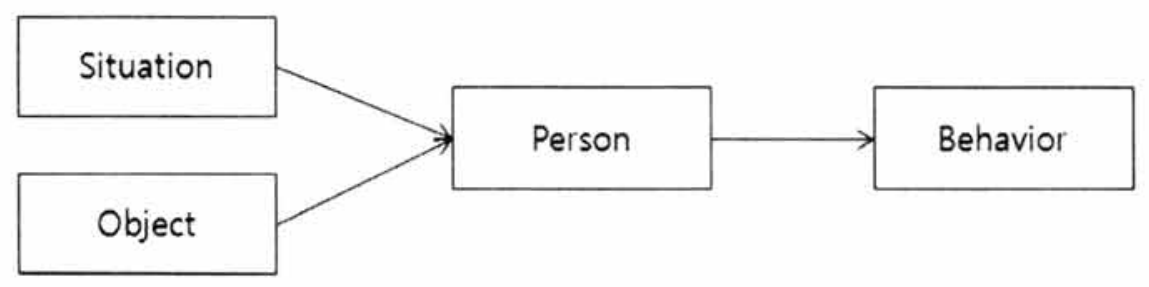

(STIMULUS)

(ORGANISM)

(RESPONSE) 
and time are the essential factors of mobile shopping. For example, public transportations, outdoor places, and commercial facilities are the most frequent places of using mobile Internet shown the KISA report, whereas the homes and workplaces are the most frequent place for PC based one.

This clue leads us to understand the consumer's situation with consumer's information searching strategies such as variety seeking. For instance, consumers may want to buy some clothes in the bus (public transportation), in the downtown (outdoor place), or in the department store (commercial facilities). The downtown or department store provide higher external stimulation to the clothes to the consumer than the public transportation situation. And the external stimulation level of department store is higher than downtown in that there are many more clothes in the department store than downtown.

This conjecture leads us to make the hypothesis that consumers with lower external stimulation level situation have tendency to search the various information the mobile shopping provider gives. So we propose that the types of product display should be matched with the consumers' level of variety seeking for achieving their positive response(see Table 3).

\subsection{Product Display Types and Information Search Behavior}

Until now, we have discussed about how situational factors affect consumers' need for information search and purchase behavior. In this perspective, we try to classify the mobile shopping situation based on the level of external stimulation of the situation, and the variety seeking behavior level differs depending on the mobile shopping situation. Thus, there are appropriate types of product display on mobile according to variety seeking behavior. Then the types of product display should be matched with the mobile shopping situation.

First of all, we review the product display types which could be utilized in the mobile shopping. To review this issue, we tried to identify the product display types of the mobile shopping applications adapted by six major Korean online shopping companies. As a result, product display types can be divided into 3 types, i.e. search, category and product presentation as shown in Figure 2. In case of search, consumer can type a keyword directly in the search box and the target products will be presented. In case of

〈Table 3〉 Variety Seeking Behavior According to External Stimulation Level

\begin{tabular}{c|c|c|c}
\hline Mobile Shopping Situation & Commercial Facilities & Outdoor Place & Public Transportation \\
\hline External stimulation level & High & Middle & Low \\
\hline Variety seeking behavior level & Low & Middle & High \\
\hline
\end{tabular}




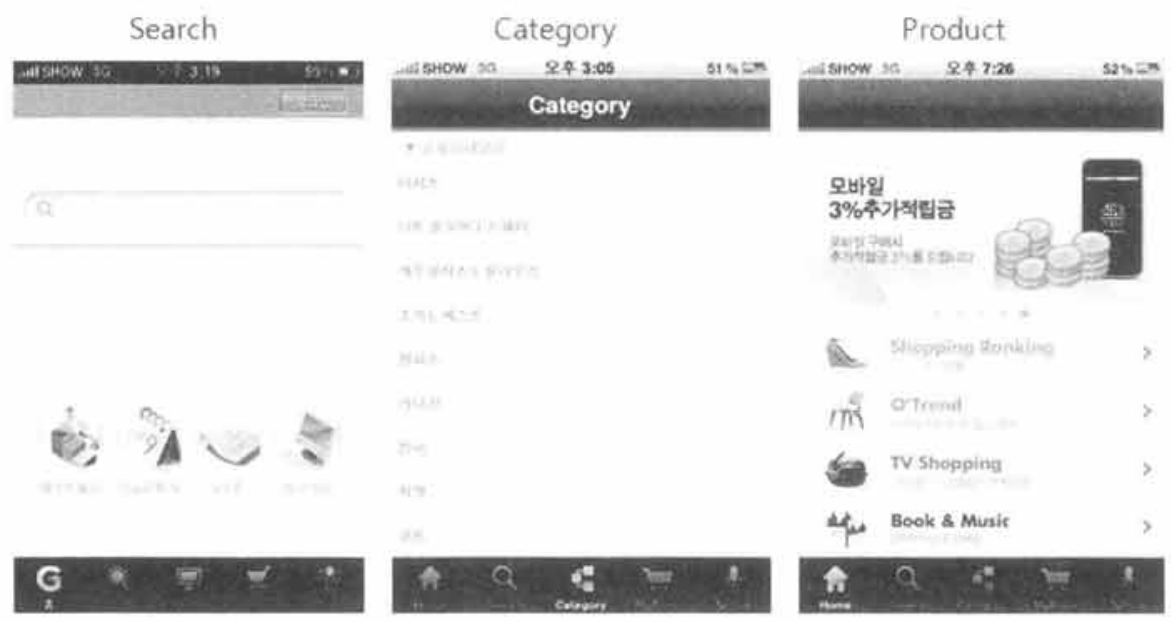

category, consumer can browse product categories or sub-categories, and they can navigate the product displays. In case of product, consumer can select a certain product or brand directly displayed in the window, and the detail product information will be presented. These types of display are also very commonly used in the field of online shopping industry, too. The question is which display type will be suitable for the various level of variety seeking tendencies in the various situations mobile Internet user could face.

According to Simonson (1990), consumers show greater variety seeking tendency when they face simultaneous choice task than sequential choice ones. From the practical viewpoint, consumer will exhibit greater variety seeking tendency when search type display is presented among the product display types because they should choose their target from the widest choice alternatives in the real world in this kind of display type. On the other hand, consumer will show lower variety seeking tendency when product type display is presented. Because the category display type makes the choice task in the intermediate level, the tendency to the variety seeking could stay in the intermediate level. For example, consumer with the search display who wants to purchase a set of summer clothes' should make his/her retrieve the right keyword among the various alternatives of $\mathrm{ca}^{-}$ tegories simultaneously, and type words "summer clothes in the search windows, and thereby his/her variety seeking tendency getting higher.

$\langle$ Table 4〉 Variety Seeking Behavior According to Product Display Types

\begin{tabular}{c|c|c|c}
\hline Product Display Type & Search & Category & Product \\
\hline Variety seeking behavior level & High & Middle & Low \\
\hline
\end{tabular}


When facing the product display, on the contrary, consumer makes his/her purchase decision between he/she take it or not, which leads to the sequential choice task. With the category display of 'summer clothes' they face the intermediate level of choice among the limited alternatives of categories, and thereby his/her variety seeking tendency will be stay in the intermediate level(Table 4).

The match-up hypothesis guides us to predict that the matching level of variety seeking tendency and information amount could result in the positive consumer responses in terms of evaluation, attitude, and purchase intentions. Therefore mobile shopping situation and product display type are matched by the variety seeking behavior level. Search is suitable product display type when consumer is in the bus, and product is appropriate for the person who is in the commercial facilities. This study asserts that the consumer responses positively with the matchup between the mobile shopping situation and product display type (Figure 3). In other words, if the mobile shopping situation and product display type match-up, consumer may have more purchase intention, positive attitude toward

〈Figure 3〉 Match-up Between the Mobile Shopping Situation and Product Display Type

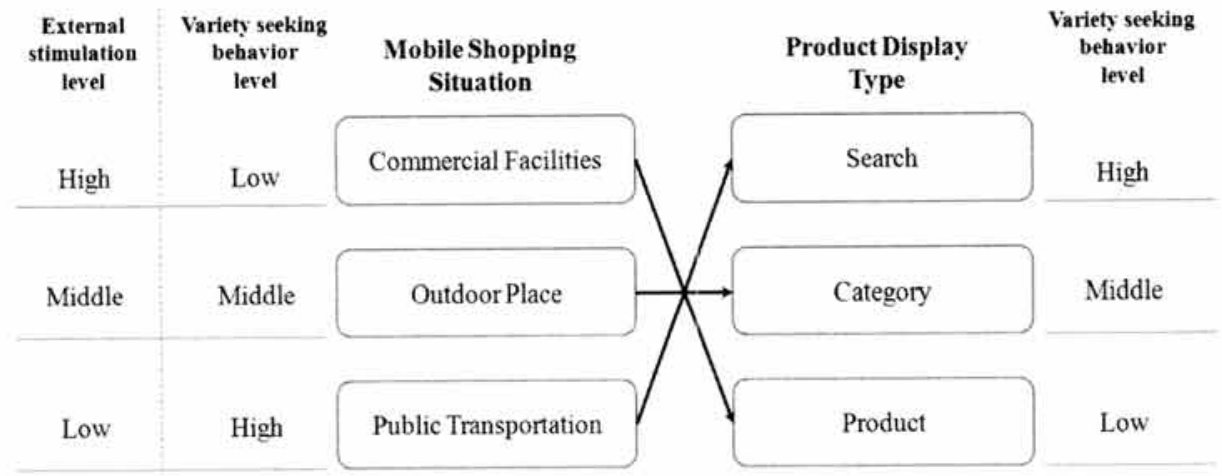

〈Figure 4〉 Research model

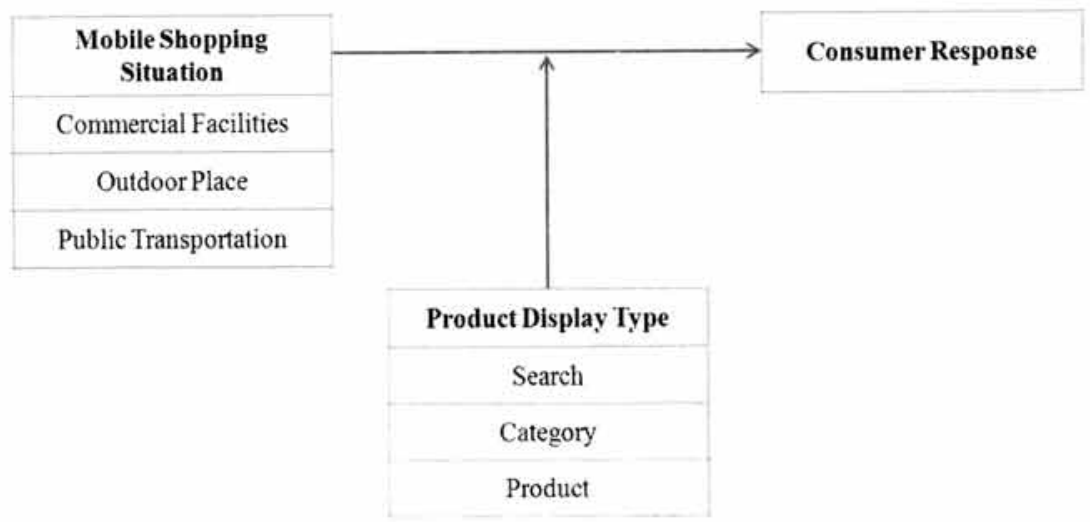

126 ASIA MARKETING JOURNAL Vol. 14 No. 03 October 2012 
store, or revisit intention.

We continue our discussion about the desirable types of product display in the mobile shopping situation. To achieve this objective, we set our research model as Figure 4.

\section{Methods and Results}

\subsection{Pretest for External Stimulation Levels of Treatments}

Pretest was designed to test the external stimulation level according to mobile shopping situation. Subjects were consisted of 40 undergraduate students. Subjects read the scenario which is described as three mobile shopping situations then they evaluated the level of interruption, for instance, the questions were how much are you bothered by surrounding environment when you are in the commercial fa- cilities? (general interruption), how much are you bothered by surrounding environment when you make the message on your Facebook page in the commercial facilities? (interruption with mobile using situation), how much are you bothered by surrounding environment when you search product information in the commercial facilities? (interruption with mobile shopping situation). Subjects were received the questionnaire out of order to prevent the order effect.

Table 5 shows the result of pretest. Commercial facilities have the highest interruption score in every interruption occasion. And outdoor place was second, followed by public transportation. Therefore, the difference of external stimulation level was identified.

\subsection{Experimental Design and Stimulus}

To test our research model, between-subjects experiment with 3 mobile shopping situations (outdoor place, public transportation, commercial

〈Table 5〉 Manipulation Check about External Stimulation Level

\begin{tabular}{|c|c|c|c|c|c|}
\hline $\begin{array}{c}\text { Interruption } \\
\text { Occasion }\end{array}$ & Mobile Shopping Situation & Mean & $\mathrm{SD}$ & $\mathrm{F}$ & Sig. \\
\hline \multirow{3}{*}{ General Interruption } & Commercial facilities & 3.925 & 1.623 & \multirow[t]{3}{*}{5.289} & \multirow[t]{3}{*}{.006} \\
\hline & Outdoor place & 3.200 & 1.786 & & \\
\hline & Public transportation & 2.725 & 1.569 & & \\
\hline \multirow{3}{*}{$\begin{array}{l}\text { Interruption with } \\
\text { Mobile Using } \\
\text { Situation }\end{array}$} & Commercial facilities & 3.475 & 1.754 & \multirow[t]{3}{*}{5.360} & \multirow[t]{3}{*}{.006} \\
\hline & Outdoor place & 2.900 & 2,023 & & \\
\hline & Public transportation & 2.200 & 1.400 & & \\
\hline \multirow{3}{*}{$\begin{array}{l}\text { Interruption with } \\
\text { Mobile Shopping } \\
\text { Situation }\end{array}$} & Commercial facilities & 3.475 & 1.853 & \multirow[t]{3}{*}{7.111} & \multirow[t]{3}{*}{.001} \\
\hline & Outdoor place & 2.950 & 2.025 & & \\
\hline & Public transportation & 2.000 & 1.377 & & \\
\hline
\end{tabular}


$\langle$ Table 6〉 Experimental Design

\begin{tabular}{|c|c|c|c|c|}
\cline { 3 - 4 } \multicolumn{2}{c|}{} & \multicolumn{3}{c|}{ Product Display Type } \\
\cline { 2 - 4 } \multicolumn{2}{c|}{} & Search & Category & Product \\
\hline \multirow{3}{*}{$\begin{array}{c}\text { Mobile Shopping } \\
\text { Situation }\end{array}$} & Outdoor Place & Type A & Type D & Type G \\
\cline { 2 - 4 } & Public Transportation & Type B & Type E & Type H \\
\cline { 2 - 4 } & Commercial Facilities & Type C & Type F & Type I \\
\hline
\end{tabular}

facilities) by 3 product display types (search, category, product) was designed by between subject.

Every mobile shopping situations and product display types were presented as in clothe buying task. The task was chosen because the largest sales come from the fashion and clothes sector in the online shopping industry. Each mobile situation was presented in a text form (scenario) with a situational picture (Figure 5) as an experimental stimulus. For instance, outdoor place scenario was presented as "...walking along the street $\cdots$ eventually you found a clothing store..." Public transportation scenario was presented as " $\cdots$ while riding a bus $\cdots$ eventually you felt a little bit hot..." and commercial facilities scenario was presented as " $\cdots$ in a clothing store $\cdots$ you look around store $\cdots "$ after each of these sequential, "you searched clothes using smart phone application" was presented. We also captured the screenshots of actual mobile shopping applications, removed company logos, and used these screenshots as experimental stimulus of product display type (Figure 2). After fully understanding about the scenario, several consumers response variables such as purchase intention, attitude toward store, and revisit intention were measured on a scale from 1 to 7 and anchored by "disagree strongly" and "agree strongly."

\subsection{Procedure}

Subjects were 197 undergraduate students

〈Figure 5〉 Examples of Stimulation

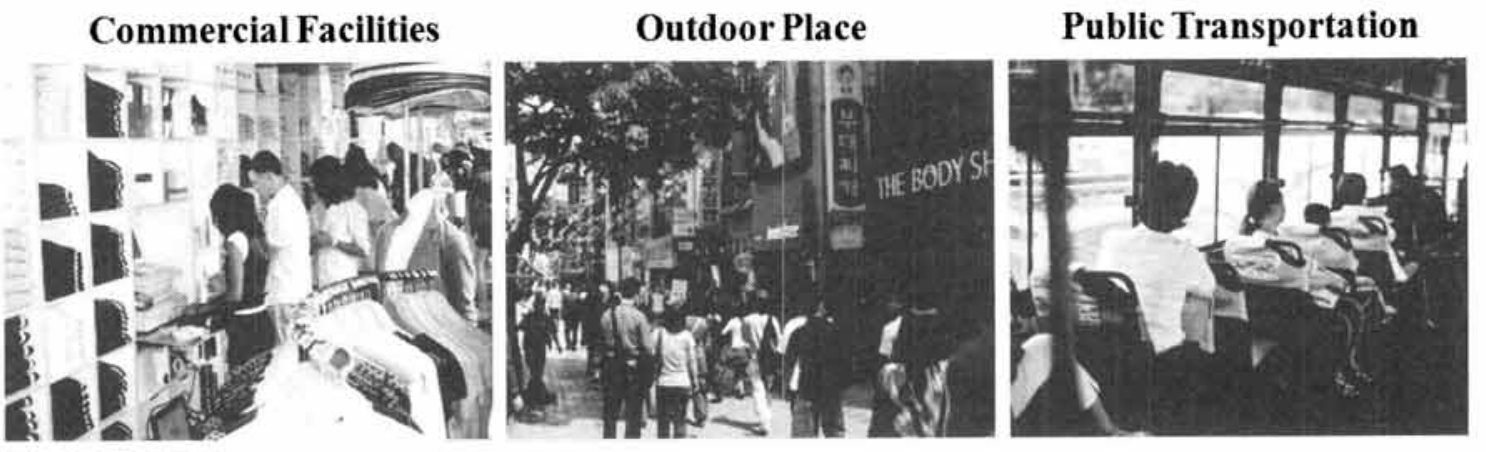

128 ASIA MARKETING JOURNAL Vol. 14 No. 03 October 2012 
from university in Korea, who participated in marketing classes. Experience was conducted before lecture without notice. In order to avoid the subjects bias, subjects were instructed that the purpose of the study was to track their mobile Internet usage behaviors. Each respondents were allocated in only one cell of the experiment design, because of the time limits and hidden research purpose they did not notice that the real purpose of the treatments. Among 197 questionnaires collected, 194 questionnaires were finally used for analysis, excluding 3 questionnaires with either left large portion of blanks or important questions unanswered. Average age of the sample was 22.3 years old and the gender was slightly skewed towards males $(52.1 \%)$. Subjects' average level of mobile shopping experience was 1.5 points out of 7 point scale, while the online shopping experience was 5.6 points.

\subsection{Manipulation Check}

We did not deliberately change the product information in the stimuli such as prices or features of product because of the external validity. So only product display types and mobile shopping situations should be manipulated between the experimental groups. But regarding the early stage of mobile commerce pose the different level of experience between the subjects, we should check the exogenous variable effects. If the usefulness of information search format and the evaluation of alternatives are significantly different by the mobile shopping situations and the product display types, we should introduce another method to control the influence of the external factors.

To measure the usefulness of information search format and the evaluation of alternatives, each variable was consisted of 3 items. As a result, reliability of each variable is .873 and .837 , and we find no statistically significant main (see Table 7) and interaction effects (see Table 8) of the mobile shopping situations and the product display types in terms of usefulness of information search format and evaluation of alternatives. Thus, we can interpret the results of the main and the interaction effects of treat-

〈Table 7〉 Manipulation Check (one-way ANOVA)

\begin{tabular}{|c|c|c|c|c|c|c|c|c|}
\hline Variable & $\begin{array}{c}\text { Mobile Shopping } \\
\text { Situation }\end{array}$ & Mean & S.D. & Sig. & $\begin{array}{c}\text { Product } \\
\text { Display Type }\end{array}$ & Mean & S.D. & Sig \\
\hline \multirow{3}{*}{$\begin{array}{c}\text { Usefulness of } \\
\text { information } \\
\text { search }\end{array}$} & Commercial facilities & 4.190 & 1.284 & \multirow{3}{*}{.587} & Search & 3.846 & 1.492 & \multirow{3}{*}{.23} \\
\hline & Outdoor place & 3.932 & 1.619 & & Category & 4.272 & 1.248 & \\
\hline & Public transportation & 4.092 & 1.361 & & Product & 4,119 & 1.490 & \\
\hline \multirow{3}{*}{$\begin{array}{l}\text { Usefulness of } \\
\text { altemative } \\
\text { evaluation }\end{array}$} & Commercial facilities & 4.354 & 1.405 & \multirow{3}{*}{.956} & Search & 4.264 & 1.465 & \multirow{3}{*}{.212} \\
\hline & Outdoor place & 4.307 & 1.348 & & Category & 4.178 & 1.317 & \\
\hline & Public transportation & 4.379 & 1.392 & & Product & 4.582 & 1.321 & \\
\hline
\end{tabular}


〈Table 8〉 Interaction Effects on the Manipulative Variables (two-way ANOVA)

\begin{tabular}{c|c|c|c|c|c}
\hline \multirow{2}{*}{ Variable } & $\begin{array}{c}\text { Mobile Shopping } \\
\text { Situation }\end{array}$ & \multicolumn{3}{|c|}{ Product Display Type } & \multirow{2}{*}{ Sig. } \\
\cline { 3 - 5 } & Search & Category & Product & \\
\hline \hline \multirow{2}{*}{$\begin{array}{c}\text { Usefulness of } \\
\text { information } \\
\text { search }\end{array}$} & Commercial facilities & $3.758(1.322)$ & $4.460(1.323)$ & $4.364(1.145)$ & \\
\cline { 2 - 5 } & Outdoor place & $3.742(1.658)$ & $4.367(1.380)$ & $3.727(1.769)$ & \multirow{2}{*}{.496} \\
\cline { 2 - 5 } & Public transportation & $4.175(1.527)$ & $3.965(0.999)$ & $4.261(1.480)$ & \\
\hline \multirow{2}{*}{$\begin{array}{c}\text { Usefulness of } \\
\text { alternative } \\
\text { evaluation }\end{array}$} & Commercial facilities & $4.091(1.306)$ & $4.206(1.631)$ & $4.758(1.231)$ & \\
\cline { 2 - 5 } & Outdoor place & $4.061(1.658)$ & $4.183(1.095)$ & $4.667(1.186)$ & \multirow{2}{*}{.479} \\
\cline { 2 - 5 } & Public transportation & $4.175(1.527)$ & $3.965(0.999)$ & $4.261(1.480)$ & \\
\hline \multirow{2}{*}{}
\end{tabular}

* The numbers in parentheses refer to standard deviation

ments on the purchase intention, attitude toward store, and revisit intention.

\subsection{Results and Discussion}

As the dependent variables, we adapted purchase intention, attitude toward store, and revisit intention to measure consumer responses between the treatments. Every item was measured in 7 point scales. Table 9 summarizes the items and result of reliability test.

To test the effects of the mobile shopping situations and the product display types on the consumer responses, we analyzed the data with ANCOVA (analysis of covariance). We con- trolled 3 covariates, i.e. subjects' mobile shopping usage experience, online shopping experience, and age to verify the pure external stimulation level in that consumer situations include all observable factors surrounding consumer controlling the individual's characteristics such as knowledge (Belk, 1974).

The results show no main effects of the mobile shopping situations and the product display types as shown Table 10. However, following the match-up hypothesis we proposed, interaction effects on the purchase intention and the revisit intention across the treatments are statistically significant. The result of the interaction effects is shown in Table 11.

〈Table 9〉 Reliability Test

\begin{tabular}{c|l|c}
\hline Variable & \multicolumn{1}{c}{ Item } & Reliability \\
\hline \hline \multirow{2}{*}{ Purchase intention } & $\begin{array}{l}\text { 1. Possibility of purchasing a product. } \\
\text { 2. Possibility of fulfilling my expectation. }\end{array}$ & .756 \\
\hline \multirow{3}{*}{ Attitude toward store } & $\begin{array}{l}\text { 1. Excitement towards the mobile shopping store } \\
\text { 2. Interest towards the mobile shopping store } \\
\text { 3. Evaluation towards the mobile shopping store }\end{array}$ & .827 \\
\hline Revisit intention & 1. Possibility of revisiting the mobile shopping store & - \\
\hline
\end{tabular}


〈Table 10〉 Main Effects on Dependent Variables (one-way ANCOVA)

\begin{tabular}{|c|c|c|c|c|c|c|c|c|}
\hline Variable & $\begin{array}{l}\text { Mobile Shopping } \\
\text { Situation }\end{array}$ & Mean & S.D. & Sig. & $\begin{array}{c}\text { Product Display } \\
\text { Type } \\
\end{array}$ & Mean & S.D. & Sig. \\
\hline \multirow{3}{*}{$\begin{array}{l}\text { Purchase } \\
\text { intention }\end{array}$} & Outdoor place & 3.484 & 1.266 & \multirow{3}{*}{.428} & Search & 3.392 & 1.590 & \multirow{3}{*}{.537} \\
\hline & Public transportation & 3.690 & 1.498 & & Category & 3.550 & 1.275 & \\
\hline & Commercial facilities & 3.400 & 1.506 & & Product & 3.627 & 1.396 & \\
\hline \multirow{3}{*}{$\begin{array}{c}\text { Attitude } \\
\text { toward } \\
\text { store }\end{array}$} & Outdoor place & 3.789 & 1.669 & \multirow{3}{*}{.537} & Search & 3.746 & 1.666 & \multirow{3}{*}{.667} \\
\hline & Public transportation & 3.929 & 1.619 & & Category & 3.967 & 1.690 & \\
\hline & Commercial facilities & 3.685 & 1.706 & & Product & 3.701 & 1.666 & \\
\hline \multirow{3}{*}{$\begin{array}{l}\text { Revisit } \\
\text { intention }\end{array}$} & Outdoor place & 3.469 & 1.699 & \multirow{3}{*}{.903} & Search & 3.292 & 1.809 & \multirow{3}{*}{.743} \\
\hline & Public transportation & 3.381 & 1.745 & & Category & 3.517 & 1.568 & \\
\hline & Commercial facilities & 3.446 & 1.687 & & Product & 3.493 & 1.727 & \\
\hline
\end{tabular}

〈Table 11〉 Interaction Effects on Dependent Variables (two-way ANCOVA)

\begin{tabular}{|c|c|c|c|c|c|}
\hline \multirow{2}{*}{ Variable } & \multirow{2}{*}{$\begin{array}{l}\text { Mobile Shopping } \\
\text { Situation }\end{array}$} & \multicolumn{3}{|c|}{ Product Display Type } & \multirow{2}{*}{ Sig. } \\
\hline & & Search & Category & Product & \\
\hline \multirow{3}{*}{$\begin{array}{l}\text { Purchase } \\
\text { intention }\end{array}$} & Outdoor place & $3.023(1.180)$ & $3.850(1.014)$ & $3.614(1.455)$ & \multirow{3}{*}{.003} \\
\hline & Public transportation & $4.333(1.658)$ & $3.053(1.235)$ & $3.630(1.479)$ & \\
\hline & Commercial facilities & $2.864(1.656)$ & $3.714(1.445)$ & $3.636(1.311)$ & \\
\hline \multirow{3}{*}{$\begin{array}{c}\text { Attitude } \\
\text { towards } \\
\text { store }\end{array}$} & Outdoor place & $3.841(1.769)$ & $4.050(1.654)$ & $3.500(1.611)$ & \multirow{3}{*}{.099} \\
\hline & Public transportation & $4.310(1.573)$ & $4.105(1.621)$ & 3.435 (1.767) & \\
\hline & Commercial facilities & $3.114(1.676)$ & $3.762(1.841)$ & $4.182(1.492)$ & \\
\hline \multirow{3}{*}{$\begin{array}{l}\text { Revisit } \\
\text { intention }\end{array}$} & Outdoor place & $3.318(1.937)$ & $3.700(1.525)$ & $3.409(1.652)$ & \multirow{3}{*}{.046} \\
\hline & Public transportation & $3.905(1.717)$ & $2.947(1.393)$ & $3.261(2.027)$ & \\
\hline & Commercial facilities & $2.682(1.701)$ & $3.857(1.682)$ & $3.818(1.468)$ & \\
\hline
\end{tabular}

* The numbers in parentheses refer to standard deviation

As shown in Figure 6, the search format generates more purchase intentions in the public transportation situation $(\mathrm{M}=4.333)$, whereas the category display produces more purchase intentions in the outdoor $(M=3.850)$ and in the commercial facilities $(M=3.714)$. In terms of the revisit intention, similar pattern is observed (Figure 7). When the consumer makes revisit intentions, they prefer search format in public transportation ( $M=3.905)$, and category display in outdoor $(\mathrm{M}=3.700)$ and in the commercial facilities $(M=3.857)$. But the gap between product display and the category display is narrowed in the commercial facilities.

Therefore, we can infer that the category display is matched to the consumers needs in the situation with the high external stimulation (outdoor place, commercial facilities), because 

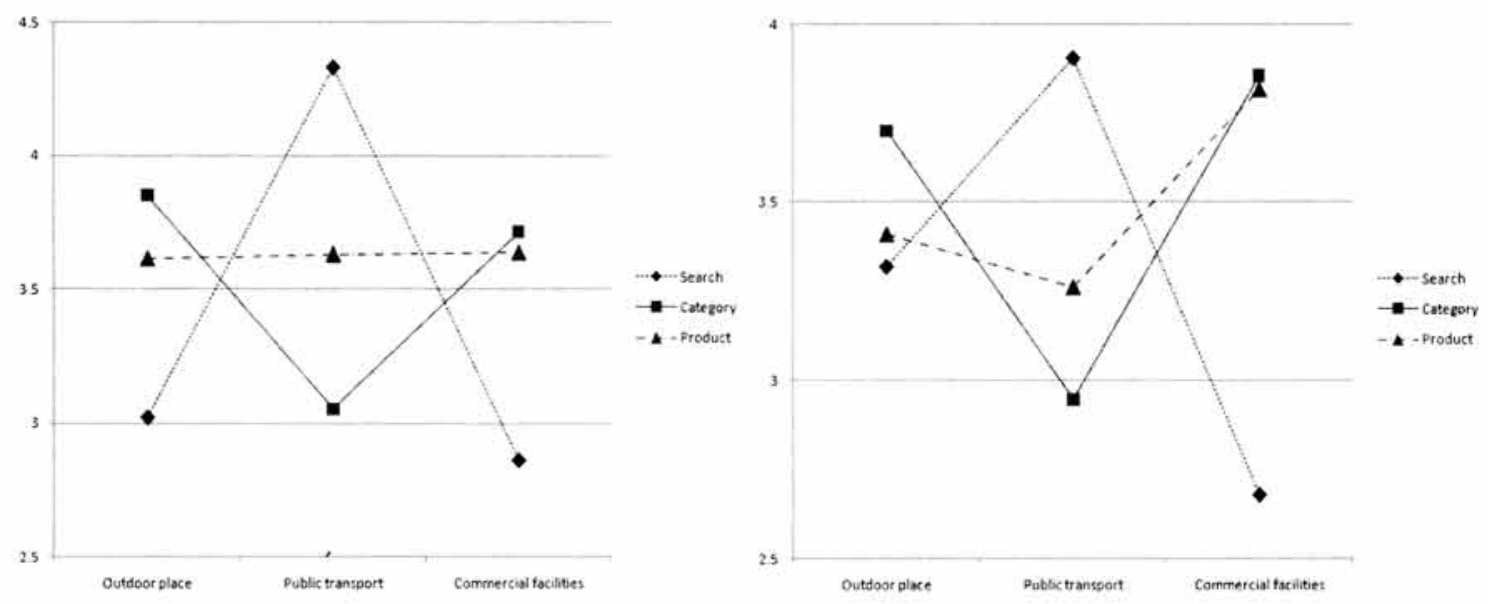

the situation lowers their variety seeking tensituational factors on the consumers' purchase dency. On the other hand, the search format is matched with the consumer's need for the information in the situation with the low external stimulation (public transportation), because it heightens variety seeking tendency. What's interesting in the result is that the attitudes toward the store are not influenced by the display types and situational factors. With the regards of the display type and the situational factors, attitude toward the store does not be influenced at all, but the purchase intention and the revisit intention are influenced by the match-up levels.

\section{Discussions and Future Direction}

Our primary goal is to investigate the interaction effects of the product display type and tention in their mobile shopping. To test the hypothesis, we classify the mobile shopping situation (outdoor place, public transportation, commercial facilities) based on the level of the external stimulation and the product display type (search, category, product) as an experimental stimulus. The result of the experiment shows that there are no main effects of the mobile shopping situations and the product display types, but the interaction effects of the product display type and the mobile shopping situation on the purchase intention and the revisit intention are statistically significant. However the attitude toward the store is not affected by the treatments.

Experiment results suggest that the consumer responses positively in terms of the purchase and revisit intention can be achieved when the product display is matched with the situation 
in the mobile shopping setting. Controlling consumers' evaluation on the product information and their experience of online shopping. we can take these effect as the results of match-up between the product display type and the situational factors surrounding mobile shopping. Thus this study verifies the match-up between mobile shopping situation and product display type in a context of external stimulation level and variety seeking behavior. This is the theoretical implication of our study.

The result provides strong support for the location-based service in mobile shopping. Most of the mobile device can utilize the consumers' location which can be easily interpreted as the situational factors. With regard of the level of the external stimulation, the shopping service providers can offer the main interface with the right match with the consumers situations. When the external stimulation level is high, they should provide the category display or product display in the target promotion in their mobile shopping apps. However if the target is on the way with the low external stimulation level. they should provide the search format as the main interface in their apps. More interestingly, this kind of manipulation affects purchase intention and revisit intention, whereas does not affect the consumers' attitude toward the store according to our research results. This is the main managerial implication of our study.

Although this study empirically tests the interaction effects of the product display type and the mobile shopping situation on the consumer responses, there are some limitations in the study to be overcome in the future research. First of all, this study shares drawback of the laboratory based experiment. The respondents were given the instructions with the scenarios and pictures to respond. Regarding the challenges of the big data from the mobile devices, it is possible to conduct a field experiments with the same design, which can enhance the external validity of the study. This kind of challenge can contribute our understanding of the consumers with the smart device with the mobility in general. Second limitation is about the definition of mobile shopping situations. In this study, we define three mobile shopping situations, commercial facilities, outdoor place, and public transportation, and these situations suppose that people just stay in these places. But it is not a common sense people use smart phone just keep standing especially considering of the essential characteristics of mobile Internet. The motive of consumers' mobility should be also explored in this regard. Thus it is necessary to redeem the mobility of the consumers in the future research.

〈Received July 20. 2012〉

〈Revised October 16. 2012〉

〈Accepted October 17. 2012〉 


\section{References}

Albers, A. (2007), "An Electronic Market Framework for Context-Sensitive Mobile Consumer Profiles in the Marketing Domain," AMCIS 2007 Proceedings, available at: http://aisel.aisnet.org/amcis2007/209 (accessed on 15 May 2011).

Na, June-Hee (2006), "Effects of Product Typicality in Usage Situation on Consumer Evaluation Toward Brand Counterextension," Journal of Korean Marketing Association, Vol. 21, No. 4, pp. 233-256.

Belk, R. W. (1974), "An Exploratory assessment of situational Effects in Buyer Behavior," Journal of Marketing Research, Vol. 11 No. 2, pp. 156-163.

Belk, R. W. (1975), "Situational Variables and Consumer Behavior," Journal of Consumer Research, Vol. 2 No. 3, pp. 157-167.

Dholakia, R. R. and N. Dholakia (2004), "Mobility and Markets: Emerging Outlines of M-Commerce," Journal of Business Research, Vol. 57 No. 12, pp. 91-96.

Frolick, M. N. and L. Chen (2004), "Assessing M-Commerce Opportunities," Information Systems Management, Vol. 21 No.2, pp. 53-61.

Jauréguiberry, F. (2000), "Mobile telecommunications and the management of time," Social Science Information, Vol. 39 No.2, pp. 255-268.
Korea Communications Commission(2011), Press Release, 3/24/2011.

Korea Chamber of Commerce \& Industry(2011), Press Release, 11/1/2011.

Korea Internet and Security Agency(2011), Mobile Internet Usage Report 2011, Seoul. Korea On-line Shopping Association(2010), Understanding and Prospect of Online Shopping 2010, Seoul.

Laszlo, J. (2009), "The New Unwired World: An IAB Status Report on Mobile Advertising," Journal of Advertising Research, Vol. 49 No.1, pp. 27-43.

Lee, Y. E. and I. Benbasat (2004), "A Framework for the Study of Customer Interface Design for Mobile Commerce," International Journal of Electronic Commerce, Vol. 8 No. 3,: 79-102.

Mennecke, B. E. and T. Strader (2001), "Where in the World deos Location Matter? A Framework for Location Based Services in M-Commerce," AMCIS 2001 Proceedings. available at: http://aisel.aisnet.org/amcis2001/ 90 (accessed on 15 May 2011).

Quester, P. G. and J. Smart (1998), "The influence of consumption situation and product involvement over consumers' use of product attribute," Journal of Consumer Marketing, Vol. 15 No. 3, pp. 220-238.

Siau, et al. (2001), "Mobile Commerce: Promise Challenges and Research Agenda," Journal of Database Management, Vol. 12 No. 3, pp. 4-13. 
Simonson, I. (1990), "The effect of purchase quantity and timing on variety-seeking behavior," Journal of Marketing Research. Vol. 27 No. 2, pp. 150-162.

Swilley, E. and C. F. Hofacker (2006), "Defining Mobile Commerce in a Marketing Context," International Journal of Mobile Marketing, Vol. 1 No.2, pp. 18-23.
Thaler, R. H. (1985), “Mental accounting and consumer choice," Marketing Science, Vol. 27 No. 1, pp. 199-214.

Walsh, A.. Davison, J. and Brown, D. (2000), Mobile E-Commerce: Market Strategies, Ovum. London. 